\title{
Carbon Enrichment of Austenite during Ferrite-bainite Transformation in Low-alloy- steel
}

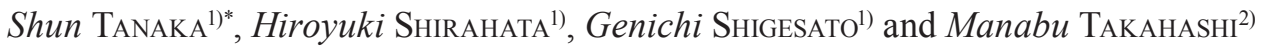 \\ 1) Steel Research Laboratories, Nippon Steel Corporation \\ 2) Department of Advanced Functional Steel for Structural Applications, Kyushu University
}

Abstract: The bainitic transformation kinetics and carbon enrichment of austenite during isothermal holding at $723-923 \mathrm{~K}$ were investigated for an Fe-0.1mass\%C-0.5mass\% $\% \mathrm{Si}-2.0 \mathrm{mass} \% \mathrm{Mn}$ alloy. The transformation progressed rapidly until approximately $50 \mathrm{~s}$, after which transformation stasis was observed at $823 \mathrm{~K}$. The carbon concentration of austenite increased as the transformation proceeded, and showed an almost constant value during stasis. It reached approximately $0.45-0.50 \%$ at $823 \mathrm{~K}$, which corresponds to the carbon concentration at the $T_{0}$ ' composition with an additional strain energy of $100 \mathrm{~J} / \mathrm{mol}$ associated with the transformation. After stasis, a slight increase in the ferrite or bainitic ferrite fraction was observed. The carbon concentration of austenite also increased and reached approximately $0.60 \%$, clearly exceeding the carbon concentration at the $\mathrm{T}_{0}$ composition. These results imply that at the first stage, the bainite transformation occurs and shows the incomplete transformation, following which at the second stage, diffusional ferrite transformation proceeds. The additional strain energy associated with the transformation calculated from the carbon concentration at stasis due to the incomplete bainite transformation tends to decrease as the holding temperature increases. This indicates that strain relaxation due to the transformation occurred at higher holding temperatures.

Keywords: low alloy steel; low carbon steel; metallography; transformation.

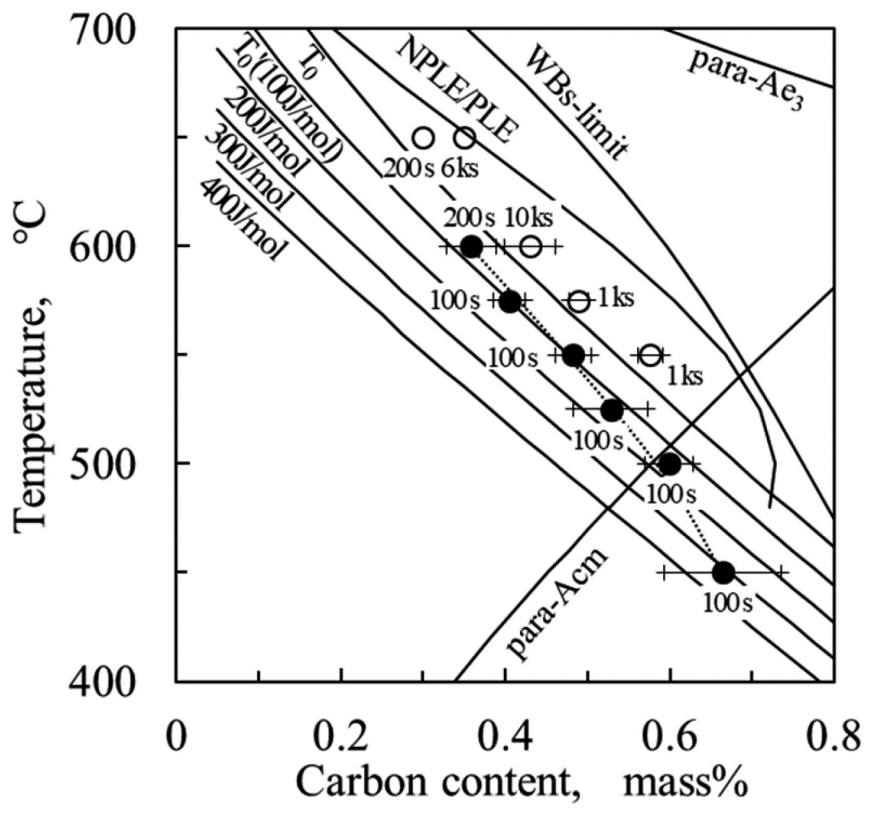

Received on Apr. 13, 2021; Accepted on Jun. 15, 2021; J-STAGE Advance published on Jul. 12, 2021

* Corresponding author. E-mail: tanaka.n9k.shun@jp.nipponsteel.com, Address: Nippon Steel Corporation, 20-1 Shintomi Futtsu Chiba 293-8511 


\title{
低合金鋼のフェライト・ベイナイト変態における オーステナイトの炭素濃化挙動
}

\author{
田中 $\quad$ 駿 $^{1) *}$ ·白幡 $\quad$ 浩幸 ${ }^{1)} \cdot$ 重里 元一 ${ }^{1)} \cdot$ 高橋 学 ${ }^{2)}$
}

Carbon Enrichment of Austenite during Ferrite-bainite Transformation in Low-alloy-steel

Shun Tanaka, Hiroyuki Shirahata, Genichi Shigesato and Manabu Takahashi

\section{1. 緒言}

\section{$1 \cdot 1$ 背景}

近年, 船舶, 建築, 海洋構造物では, 大型化や軽量化が進 み, 構造部材に用いられる厚鋼板には高強度化が求められ ている。高強度化のため, 従来のフェライト組織ではなく, ベイナイト組織の活用が必須である。一方, ベイナイト組 織では, ベイニティックフェライト $(\mathrm{BF})$ 間の残留オース テナイト $(\gamma)$ の一部が硬質なマルテンサイトとなることで, それが脆化相となり, 鋼の勒性が顕著に劣化する場合があ $る^{1,2)}$ 。

また，自動車部材に用いられる高張力鋼板 (ハイテン) には, 軽量化や加工性向上のために, 強度, 延性バランス の向上が求められている。この要求を満足するため, ベイ ナイト，残留 $\gamma$ を含む複合組織鋼での TRIP (Transformation Induced Plasticity）現象の活用が積極的に進められている。 ここでは特に, 残留 $\gamma$ の安定性向上が重要である 3.4 。

このように, 近年の高機能鋼板の開発においては, 残留 $\gamma$ の形成機構を解明する必要がある。特に, フェライト变態 およびベイナイト変態に伴う未变態 $\gamma$ へ炭素 (C) の分配 挙動の把握が求められる。このためには, $\mathrm{Ae}_{3}$ 点以下の等 温保持に打けるフェライト変態打よびベイナイト変態のメ カニズムを詳細に理解し, 高い精度で残留 $\gamma$ の濃度を予 測する必要がある。

\section{$1 \cdot 2$ 変態停留メカニズム}

ベイナイト変態に扔いて, 等温保持中に変態が停止する 現象 (不完全変態) が知られている。この不完全変態のメ カニズムについては, ベイナイト変態を (i) 無拡散変態 (せ 几断変態) ${ }^{5-8}$ と捉えるか, (ii) Cの拡散律速変態 ${ }^{9-12}$ と捉 えるかで解釈が異なっており, ベイナイト変態に伴って未 変態 $\gamma$ にが濃化する上限の濃度で多くの議論がされてい る。 (i) 無拡散変態と捉える立場では, ベイニティックフェ ライト $(\mathrm{BF})$ の自由エネルギー $\left(G_{\mathrm{bcc}}\right)$ にひずみエネルギー などに対応する過冷度 $(\Delta)$ を上乗せした自由エネルギー $\left(G_{\mathrm{bcc}}+\Delta\right)$ とүの自由エネルギー $\left(G_{\mathrm{fcc}}\right)$ が等しくなる組成 （ $\mathrm{T}_{0}{ }^{\prime}$ 組成）に達するとべイナイト変態が停止するとされる。 このモデルは, Zenerにより提案された $\mathrm{T}_{0}$ 組成 ${ }^{13)}$ に対して, Bhadeshiaがこれを拡張したものであり, $\mathrm{T}_{0}{ }^{\prime}$ モデルとして 知られている ${ }^{5,6)}$ 。Bhadeshiaはべイナイト変態の過冷度 $(\Delta)$ を $400 \mathrm{~J} / \mathrm{mol}$ 程度と見積もっている ${ }^{5,6)}$ 。無拡散変態と捉え る立場では, ベイナイト変態に伴う変態停留が生じるとき の C 濃度は $\mathrm{T}_{0}$ 組成からの過冷度で特徴づけられるとして いる。

これに対して, (ii) Cの拡散律速変態と捉える立場で は, ウィッドマンステッテンフェライト (WF) と BFの生 成メカニズムは本質的には同じであると考元, 両者を含 めてアシキュラーフェライトとする。Hillertは, アシキュ ラーフェライトの成長には, 熱力学的障壁 (Thermodynamic barrier）が存在し, 成長限界となるときのC濃度は, para平 衡となるC濃度よりも低C側になることを見出し, アシ キュラーフェライトの成長限界となる組成をWBs 組成と している, ${ }^{9,10)}$ 。すおお，Cの拡散律速変態と捉える立場で は, ベイナイト変態に伴う変態停留が生じるときのC濃度 はpara-Ae 3 からの過冷度 $(\Delta G)$ で特徵づけられるとしてい る。近年, Furuhara, Miyamotoらの研究グループでは, Fe$(1.5,3 \%) \mathrm{Si}-0.4 \% \mathrm{C}$ 合金を $400^{\circ} \mathrm{C}$ および $450^{\circ} \mathrm{C}$ で等温保持し

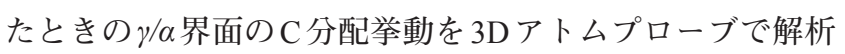
し, $\gamma / \alpha$ 界面近傍の未変態 $\gamma$ の 濃度が $\mathrm{T}_{0}{ }^{\prime}(400 \mathrm{~J} / \mathrm{mol})$ 組成 および $\mathrm{T}_{0}$ 組成のC濃度を大きく超えた実験結果から, $\mathrm{T}_{0}{ }^{\prime}$ モデルでは不完全変態メカニズムを説明できず, para- $\mathrm{Ae}_{3}$ からの過冷度 $(\Delta G)$ で評価 (WBsモデル) すると実験結果 をよく説明できるとしている ${ }^{14,15)}$ 。

ベイナイトの不完全変態メカニズムを明確にするために

2021年4月13日受付２021年6月15日受理２021年7月12日J-STAGE早期公開（Received on Apr. 13, 2021; Accepted on Jun. 15, 2021; J-STAGE Advance published on Jul. 12, 2021)

1）日本製鉄 (株) 鉄鋼研究所 (Steel Research Laboratories, Nippon Steel Corporation)

2）九州大学大学院総合理工学研究院 (Department of Advanced Functional Steel for Structural Applications, Kyushu University)

* Corresponding author. E-mail: tanaka.n9k.shun@jp.nipponsteel.com, Address: Nippon Steel Corporation, 20-1 Shintomi Futtsu Chiba 293-8511 
は, フェライト変態を抑制するための実験条件の選定が重 要である。そのため, 従来報告されているものの多くは, 等温保持中に拡散変態が生じにくい $500^{\circ} \mathrm{C}$ 以下で検討がさ れている。しかしながら, 保持温度が低温になるほど $\mathrm{T}_{0}$, 組 成の C 濃度と WBs 組成の C 濃度が接近し ${ }^{16)}$ ，いずれのメカ ニズムに従うかの判断が難しい。また, 高温で保持して金 属組織を $\gamma$ 化したのち急冷して等温保持する際に, 保持温 度より高温でのフェライト変態を抑制する必要がある。そ のため, Mnなどの $\gamma$ 安定化元素を添加して検討されること が多い。一方で $\mathrm{T}_{0}$ 組成を超えてWBs モデルに従うと主張 する上述の報告 ${ }^{14)}$ は, 焼入れ性が顕著に低い Fe-Si-C系で 検討されたものであり, 冷却過程でフェライト変態が生じ る可能性に留意する必要がある。

一方, フェライト変態の場合, 不分配局所平衡 (NoPartition Local Equilibrium, NPLE) と分配局所平衡 (Partition Local Equilibrium, PLE) の境界 (NPLE/PLE境界) でC 拡散 律速の変態モードから置換型合金元素の拡散律速の変態 モードに切り替わることで, 変態が著しく遅くなるため, 変態が停止するように見える ${ }^{17-20)}$ 。Liuら, Furuharaらは, Fe-C-(1.5 - 2.0) mass\%Mn合金を $650-725^{\circ} \mathrm{C}$ で等温保持し た場合, フェライト変態し, 未変態 $\gamma$ の 濃度がNPLE/PLE 境界まで上昇することを確認している。また， $600-650^{\circ} \mathrm{C}$ では, NPLE/PLE境界までC濃化せず, NPLE/PLE境界から 低C側に外れていくと報告している ${ }^{21,22)}$ 。

\section{$1 \cdot 3$ 本研究の目的}

これまで述べたように, ベイナイト変態に伴う変態停留 メカニズムについては $500^{\circ} \mathrm{C}$ 以下，フェライト変態に伴う 変態停留メカニズムについては $650^{\circ} \mathrm{C}$ 以上で主に検討され ている。しかしながら，実用鋼で用いられる低合金組成に

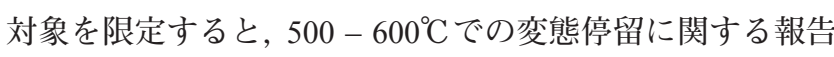
例は少なく，いずれのメカニズムによって変態停留が生じ るか明確ではない。一方で, 残留 $\gamma$ の濃度を高精度で予測 するためには，いずれのメカニズムによるかを明確化し， 特にべイナイト変態については, 過冷度の定量的評価が求 められる。

本論文では, $\mathrm{Fe}-\mathrm{C}-\mathrm{Si}-\mathrm{Mn} 4$ 元系モデル合金を $450-$ $650^{\circ} \mathrm{C}$ で等温保持し, 変態停止時およびその前後の未変態 $\gamma$ のC濃度を測定することで, 変態停止のメカニズムを検討 した。

\section{2. 実験方法}

\section{$2 \cdot 1$ 供試鋼・状態図}

本研究の供試鋼は, Table 1 に示す化学成分であり, 真 空溶解炉で作製した。Thermo-calcで熱力学計算した Fe$0.5 \mathrm{mass} \% \mathrm{Si}-2.0 \mathrm{mass} \% \mathrm{Mn}-\mathrm{C}$ 合金の状態図を Fig.1に示す。 データベースはTCFE8を用いた。Mnを $2 \%$ 添加すること により, 今回検討する温度範囲において, ベイナイト変態
に伴う変態停留時の成分が $\mathrm{T}_{0}$, 組成, WBs 組成のいずれに 従うかの区別が明確な合金組成となっている。また, Siを 添加することで, 未変態 $\gamma$ へ C 濃化が進むことによる炭 化物析出の抑制を志向した。これにより, 変態停留時に炭 化物析出による新たな $\alpha$ 変態を抑制し, 極力, $\alpha$ と $\gamma$ 二相 で変態停留現象を評価することを試みた。

\section{$2 \cdot 2$ 熱処理条件}

$50 \mathrm{~kg}$ インゴットを鋳造し, $1100^{\circ} \mathrm{C} \times 3600 \mathrm{~s}$ 加熱後に板厚 $20 \mathrm{~mm}$ まで熱間圧延した。凝固に伴うミク口偏析を緩和す るため, 圧延材から切り出した棒状試験片を $\mathrm{Ar}$ 雲囲気の石 英管に封入し, $1300^{\circ} \mathrm{C} \times 21.6 \mathrm{ks}$ の均質化処理を施した。均 質化処理を施した棒状試験片から $3 \mathrm{~mm} \phi \times 10 \mathrm{~mm}$ (熱電対 取付けのため $2 \mathrm{~mm} \phi \times 3 \mathrm{~mm}$ 深さの穴加工を付与) の試験 片を採取した。採取した試験片に対して, フォーマスタ試 験機 (富士電波工機社製) を用いて高周波熱処理を行いな がら, 温度変化に対する線膨張量の変化を測定した。熱処 理は, $1400^{\circ} \mathrm{C} \times 3 \mathrm{~s}$ 保持で金属組織を $\gamma$ 化した後, 直ちに $\mathrm{He}$ ガスで急冷 $\left(100^{\circ} \mathrm{C} / \mathrm{s}\right.$ 冷却 $) し, 450-650^{\circ} \mathrm{C}$ で $10-10000 \mathrm{~s}$ 等 温保持した後, 室温までHeガスで急冷した。なお, Grange らの化学組成を用いた Ms 点の簡易式 ${ }^{23)}$ から, Ms $\fallingdotseq 436{ }^{\circ} \mathrm{C}$ と推定される。

高温での $\gamma$ 組織を急冷し，等温保持が開始される前に， (1)高温でフェライト変態が生じないこと, (2) Ms 点を下回 らないこと, を確認することを目的に, 種々の冷却速度で 室温まで冷却した試料の金属組織観察とビッカース硬さ測 定を予備実験として実施した。試料の円柱断面を鏡面研磨 した後, 3\%Nital液でエッチングを施し, 光学顕微鏡にて金 属組織を観察した。ビッカース硬さは, 荷重 $10 \mathrm{kgf}$ ○゙ 点 圧下した平均值として求めた。

Table 1. Chemical composition of test steel.

\begin{tabular}{ccccccccc}
\hline $\mathrm{C}$ & $\mathrm{Si}$ & $\mathrm{Mn}$ & $\mathrm{P}$ & $\mathrm{S}$ & $\mathrm{Al}$ & $\mathrm{Ti}$ & $\mathrm{N}$ & $\mathrm{O}$ \\
\hline 0.099 & 0.50 & 2.02 & $<0.002$ & 0.0006 & 0.030 & $<0.002$ & 0.0006 & $<0.001$ \\
\hline
\end{tabular}

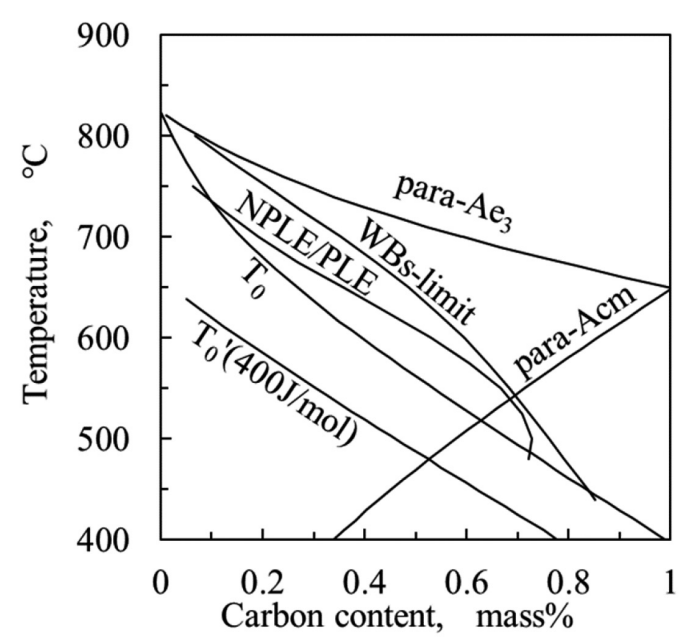

Fig. 1. Phase diagram of Fe-C-0.5Si-2.0Mn system. 


\section{$2 \cdot 3$ 未変態 $y$ の 濃度の測定方法}

$450-650^{\circ} \mathrm{C}$ で等温保持した試料の円柱断面を鏡面研磨し た後, LePeraエッチングを施し, 光学顕微鏡またはSEMで 金属組織を観察し，マルテンサイトに変態している部分を 確認した。このマルテンサイトは，等温保持し，室温まで 急冷を開始する直前に未変態 の後，エッチングによる凹凸の影響を除去するため，再度 鏡面研磨を施し，金属組織を観察した同視野のC濃度分布 を電界放出型電子線プローブマイクロアナライザー（FEEPMA：JXA-8500F 日本電子社製）で測定した。FE-EPMA による測定は, 加速電圧 $7 \mathrm{kV}$, 照射電流 $5 \times 10^{-8} \mathrm{~A}, 1$ 点あ たりの照射時間 $50 \mathrm{msec}$ で行った。Cコンタミネーション の影響を極力抑制するため，(i) 研磨後にアルゴンイオン ビームの照射によるスパッタリング，(ii) 液体窒素トラッ プ，(iii）照射時間の短縮，を施した。Cの定量は, Fe-C合 金標準試料を用いた検量線法で行った。標準試料は, C 量 をさまざま変化させた $\mathrm{Fe}-\mathrm{C}$ 合金を鍛造・圧延打よび焼入 れ処理などを施すことで，均一な Cの濃度分布を有してい る。C濃度に換算した標準誤差は $\sigma= \pm 0.03 \mathrm{mass} \%$ である (Fig.2)。各 $\gamma$ 粒 (室温で測定するときはマルテンサイト) の $\mathrm{C}$ 濃度は, $\gamma$ 粒内で粒界を含まない領域 $(0.4 \mu \mathrm{m} \times 0.4 \mu \mathrm{m}$ 以

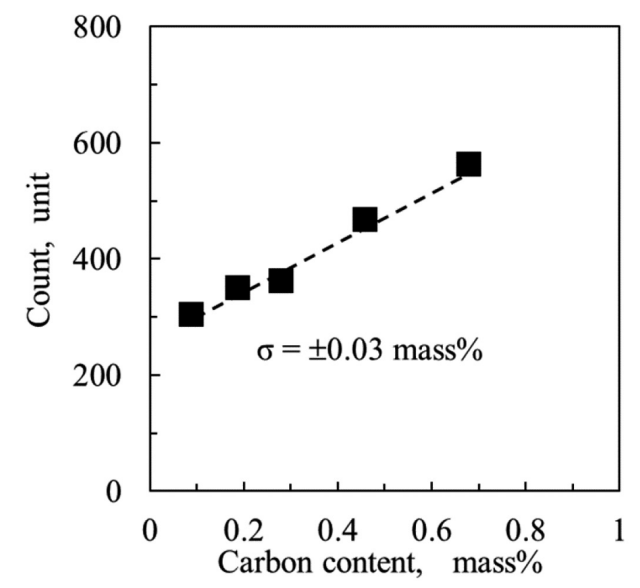

Fig. 2. Calibration line of carbon content for FE-EPMA measurements.
上）の平均值で評価した。また, 測定する $\gamma$ 粒は粒径 $2 \mu \mathrm{m}$ 以上の粗大なもの, かつ, C濃度が高いものを選択した。こ れは, $\gamma$ 粒界近傍はビームの広がりによって, ベイナイトま たはフェライト母地の影響を受けるため, $\gamma$ C濃度を正 しく評価できない恐れがあるためである。なお，純鉄にお ける特性X線の侵入深さは Castaingの式 ${ }^{24)}$ から $0.25 \mu \mathrm{m}$ 程 度であり, 深さ方向に打ける母地の影響は無視できると考 えられる。各熱履歴を付与した試料において，それぞれ 10 個の $\gamma$ 粒を選択し，前述の方法で $\gamma$ 粒のC濃度を評価し，そ れらの平均值を未変態 $\gamma$ の濃度とした。誤差表記につい ては 10 個の $\gamma$ 粒に打ける C 濃度がその平均值周りの正規分 布に従うと仮定し，標準偏差 $1 \sigma$ を実験誤差とした。

\section{3. 実験結果}

\section{$3 \cdot 1$ 連続冷却した供試鋼の金属組織}

種々の冷却速度に対するビッカース硬さと $\mathrm{Ar}_{3}$ 点を Table 2 に $100^{\circ} \mathrm{C} / \mathrm{s}, 10^{\circ} \mathrm{C} / \mathrm{s}, 1{ }^{\circ} \mathrm{C} / \mathrm{s}$ で冷却したときのNital腐食し た金属組織の光学顕微鏡写真を Fig. 3 に示す。 $100^{\circ} \mathrm{C} / \mathrm{s}$ の冷 却の場合，金属組織は全面マルテンサイトであり，粒界 フェライト $(\mathrm{GBF})$ の生成は認められなかった。また, 固 溶 $\mathrm{C}$ 濃度とマルテンサイト硬さの関係 ${ }^{25)}$ とビッカース硬 さの比較からも Ms 点を切って生成したマルテンサイトで あると判断した。この結果から, $450^{\circ} \mathrm{C}$ 以上の等温保持にあ たり, 急冷 $\left(100^{\circ} \mathrm{C} / \mathrm{s}\right)$ 途中に $\gamma \rightarrow \alpha$ 変態が生じないことが確 認された。べイナイト変態開始温度（Bs点）より低温で生 成するラス状または針状の BCCを BF と定義した。種々の 冷却速度の連続冷却で得られる金属組織と変態開始温度か ら, Bs 点は $610^{\circ} \mathrm{C}$ 近傍と判断した。Kawata ${ }^{26)}$ は, Bs 点は

Table 2. Vickers hardness and experimental $\mathrm{Ar}_{3}$ temperatures of the steel cooled at various cooling rates.

\begin{tabular}{l|ccccccc} 
Cooling rate $\left({ }^{\circ} \mathrm{C} / \mathrm{s}\right)$ & 100 & 50 & 10 & 5 & 1 & 0.5 & 0.1 \\
\hline Vickers Hardness $(\mathrm{Hv})$ & 354 & 340 & 247 & 200 & 179 & 171 & 147 \\
Experimental $\mathrm{Ar}_{3}\left({ }^{\circ} \mathrm{C}\right)$ & 400 & - & - & 610 & - & - & 711
\end{tabular}
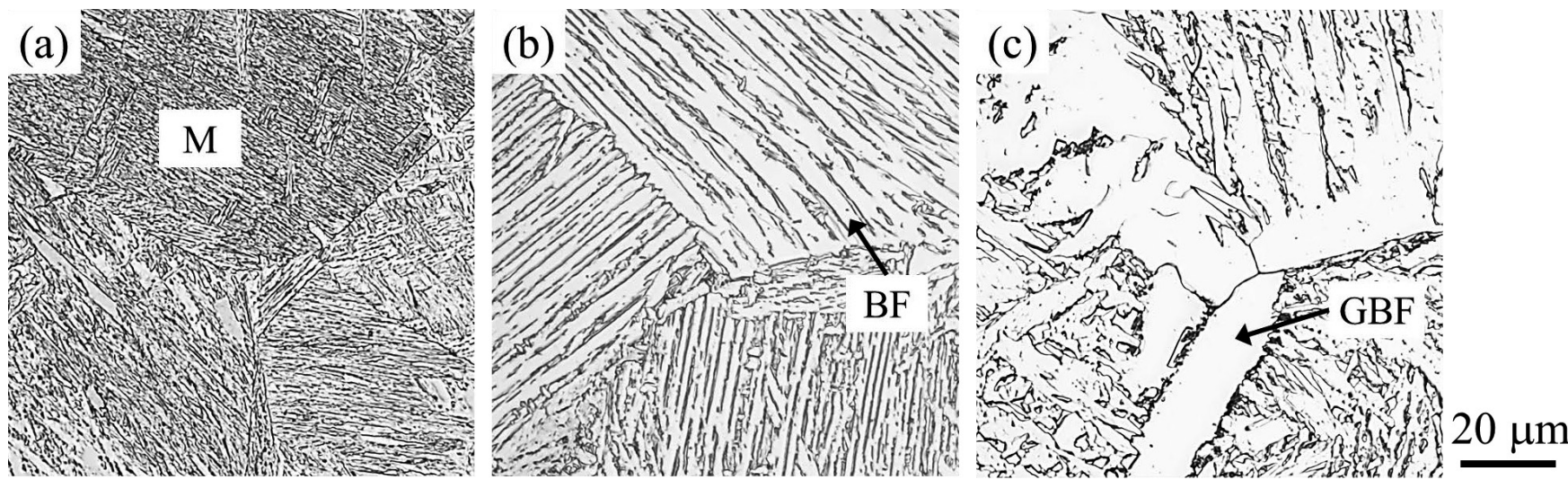

Fig. 3. Optical micrographs of Nital etched microstructure cooled at (a) $100^{\circ} \mathrm{C} / \mathrm{s}$, (b) $10^{\circ} \mathrm{C} / \mathrm{s}$ and (c) $1{ }^{\circ} \mathrm{C} / \mathrm{s}$. 
$\mathrm{T}_{0}{ }^{\prime}(400 \mathrm{~J} / \mathrm{mol})$ に対応すると述べている。本研究の供試鋼 に打ける $\mathrm{T}_{0}{ }^{\prime}(400 \mathrm{~J} / \mathrm{mol})$ は $620^{\circ} \mathrm{C}$ に相当することから, 連 続冷却から見積もられる $\mathrm{Bs}$ 点は妥当と考えられる。1 $0^{\circ} \mathrm{C} / \mathrm{s}$ で泠却すると, Bs 点以下の温度で変態開始し, 金属組織は ラス状の $\mathrm{BF}$ であった。一方, $1^{\circ} \mathrm{C} / \mathrm{s}$ で冷却すると, $\mathrm{Bs}$ 点以 上で変態開始し，旧 $\gamma$ 粒界近傍に塊状のフェライトが生成 した。

\section{$3 \cdot 2$ 等温保持した供試鋼の金属組織と膨張曲線}

$650^{\circ} \mathrm{C}$ で等温保持したときの線膨張量の時間変化と金属 組織のSEM像を Fig.4に示す。金属組織は, 粒界フェライ

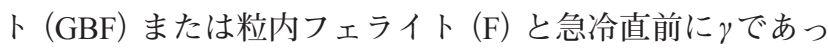
た部分が急冷時に変態したマルテンサイト $(\mathrm{M}(\mathrm{A}))$ で構 成された。フェライト変態に伴う膨張が進み, $6000 \mathrm{~s}$ 程度 まで変態停留は見られなかった。また，6000 s保持しても 未変態 $\gamma$ か炭化物の析出は見られなかった。

$600^{\circ} \mathrm{C}$ で等温保持したときの線膨張量の時間変化と金属 組織の SEM像を Fig.5に示す。膨張曲線から $100 \mathrm{~s}$ 程度まで 急激に変態が進み, その後, 緩やかに変態が進んだ。急激 に変態が進んだ直後に急冷した金属組織 $(F i g .5$ (b)) では, BFが生成した。10000 s保持すると, BF間の未変態 $\gamma$ の一 部が分解したような金属組織 (Fig.5 (c) ) を呈した。これは, 炭化物 $(\theta)$ 析出を伴う FCC $\rightarrow$ BCC 変態によって生じた金 属組織 $(\alpha+\theta)$ と推察される ${ }^{27)}$ 。

$550^{\circ} \mathrm{C}$ で等温保持したときの線膨張量の時間変化と金属
組織のSEM像を Fig.6に示す。等温保持開始後, 直ちに膨 張が生じた後, $50-300 \mathrm{~s} て ゙$ 膨張が停止し, 変態停留が生じ た。保持開始後, $300 \mathrm{~s}$ 以降は緩やかに膨張が進んだ。金属 組織は BF主体であり，BFラス間にはM (A) が生成した。 変態停留が生じた $300 \mathrm{~s}$ 以下では, BF ラス間には炭化物の 生成は見られなかった。一方，長時間保持 $(>1000 \mathrm{~s})$ では, $\mathrm{BF}$ のラス間の未変態 $\gamma$ の一部が炭化物析出を伴う $\mathrm{FCC} \rightarrow$ $\mathrm{BCC}$ 変態によって生じた $\alpha+\theta$ の金属組織を呈した。

$500^{\circ} \mathrm{C}$ および $450^{\circ} \mathrm{C}$ で等温保持したときの線膨張量の時 間変化と金属組織のSEM像を Fig.7 に示す。等温保持開始 後, 直ちにベイナイト変態に伴う膨張が生じ, $20 \mathrm{~s}$ 程度で 膨張が停止した。膨張停止直後に急冷した試料では, BF ラ 不間に M (A) が生成した。1000 $\mathrm{s}$ 以上保持しても膨張の再 開は見られなかった。長時間保持するほど, BFラス間の炭 化物 $(\theta)$ が増加し, M (A) 即ち未変態 $\gamma$ は膨張停止直後に 比べて減少した。 $450^{\circ} \mathrm{C}$ 保持材のほうが $500^{\circ} \mathrm{C}$ 保持材に比べ てBFラス間の $\gamma$ の炭化物への分解が進んだ。

\section{$3 \cdot 3$ 未変態 $\gamma$ の濃度評価}

$600^{\circ} \mathrm{C}$ で $200 \mathrm{~s}, 10000 \mathrm{~s}$ 保持したときの金属組織の SEM 写真と同視野に打ける FE-EPMAによるCの2次元マッピ ング画像打よびCの線分析の一例を Fig.8に示す。Fig.5 (a) に示す膨張曲線によれば, $200 \mathrm{~s}$ はベイナイト変態に伴う急 激な膨張が停止した直後であり，緩やかな膨張が開始する 時刻に, $10000 \mathrm{~s}$ は再度膨張が進行している時刻にそれぞれ
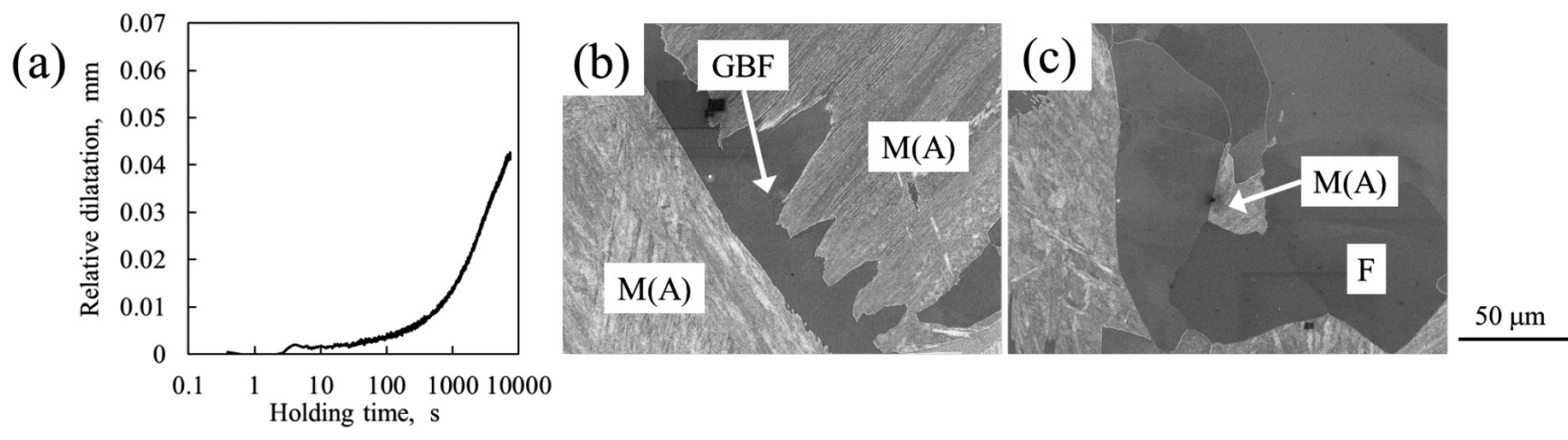

Fig. 4. (a) Dilatation during isothermal holding at $650^{\circ} \mathrm{C}, \mathrm{SEM}$ images after (b) $200 \mathrm{~s}$ and (c) $6000 \mathrm{~s}$ of isothermal holding.
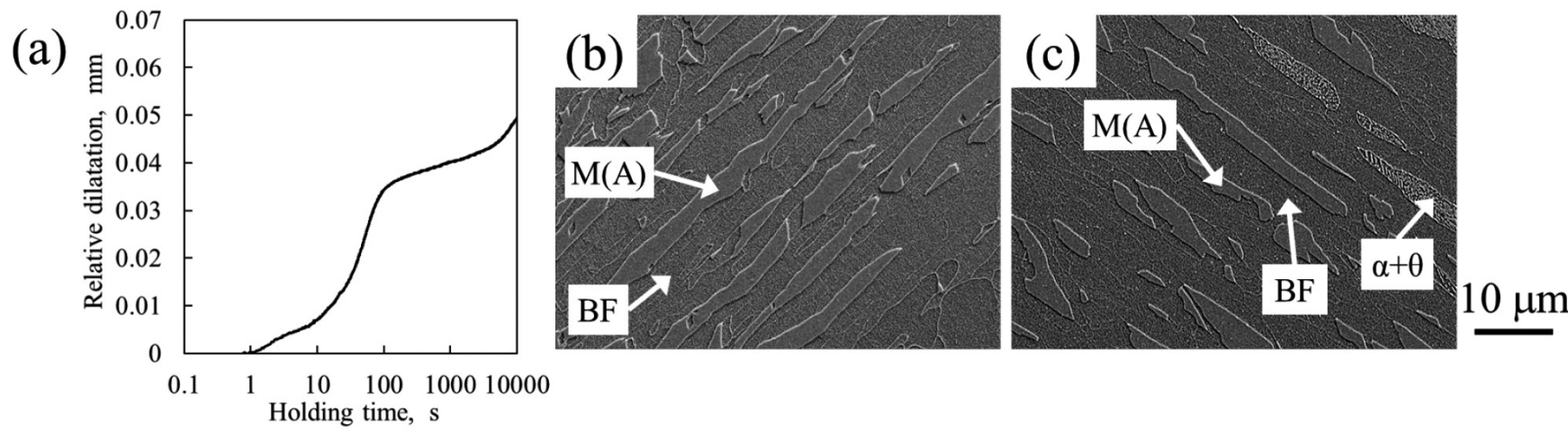

Fig. 5. (a) Dilatation during isothermal holding at $600^{\circ} \mathrm{C}$, SEM images after (b) $200 \mathrm{~s}$ and (c) $10000 \mathrm{~s}$ of isothermal holding. 
相当する。このときのBFラス間の未変態 $\gamma$ (室温まで急冷

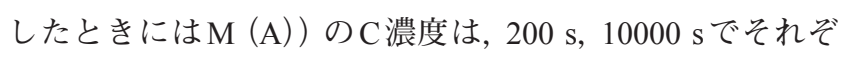
れ, $0.36 \pm 0.03 \%, 0.43 \pm 0.03 \%$ であった。

$550^{\circ} \mathrm{C}$ で $100 \mathrm{~s}, 1000 \mathrm{~s}$ 保持したときの金属組織のLePera 腐食光学顕微鏡写真と同視野における FE-EPMAによるC の2次元マッピング画像およびCの線分析の一例を Fig.9に 示す。Fig.6 (a) に示す膨張曲線によれば, 100 sはべイナイ 卜変態が進まず変態停留している時刻に, $1000 \mathrm{~s}$ は変態停 留が終了し, 変態に伴う線膨張の増加が再開している時刻 にそれぞれ相当する。このときのBFラス間の未変態 $の C$ 濃度は，100 s, $1000 \mathrm{~s}$ でそれぞれ $0.48 \pm 0.02 \%, 0.58 \pm 0.02$ \%であった。
同様の手法に扔いて, $500^{\circ} \mathrm{C}, 450^{\circ} \mathrm{C} て ゙ 100 \mathrm{~s}$ 保持したとき のBFラス間の未変態 $\gamma$ の $\mathrm{C}$ 濃度は, それぞれ, $0.60 \pm 0.03$ $\%, 0.66 \pm 0.07 \%$ に達していた (Fig.10)。

\section{4. 考察}

\section{$4 \cdot 1550^{\circ} \mathrm{C}$ おび $500^{\circ} \mathrm{C}$ 保持における未変態 $\gamma$ の C濃度の 時間変化}

$550^{\circ} \mathrm{C}$ 保持における未変態 $\gamma$ の C 濃度の時間変化を Fig. 11 (a)に示す。変態停留は50-300 sの間で生じて打り，その 後, 再度膨張が再開した。変態停留時の未変態 $\gamma$ の 濃度 は, $\mathrm{T}_{0}$ '組成の $C$ 濃度に相当し, $T_{0}$ 組成からの過冷度 $(4)$ は (a)

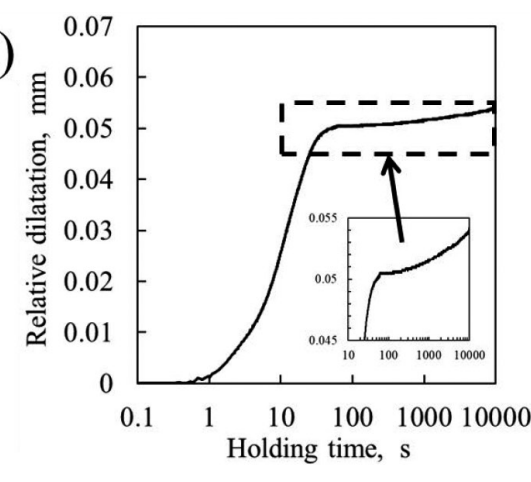

$10 \mu \mathrm{m}$
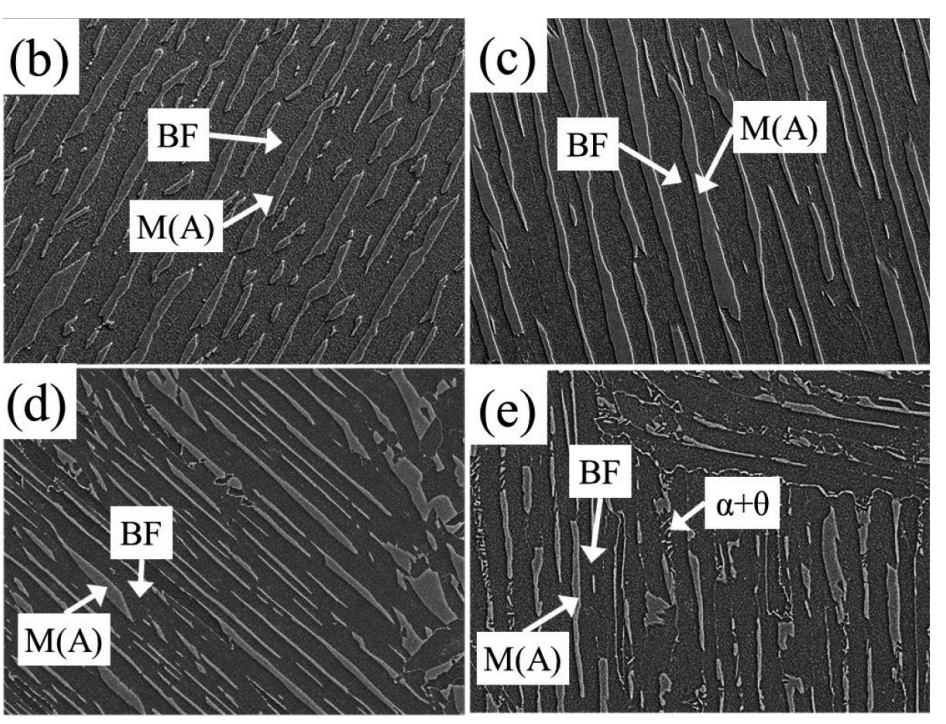

Fig. 6. (a) Dilatation during isothermal holding at $550^{\circ} \mathrm{C}, \mathrm{SEM}$ images after (b) $30 \mathrm{~s}$, (c) $200 \mathrm{~s}$, (d) $1000 \mathrm{~s}$ and (e) $10000 \mathrm{~s}$ of isothermal holding.

(a)

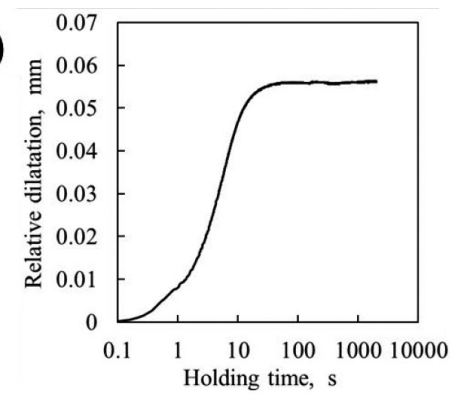

(d)

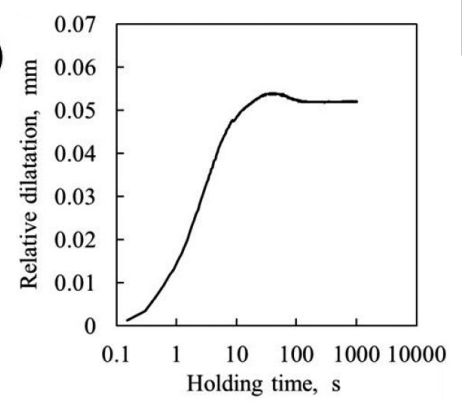

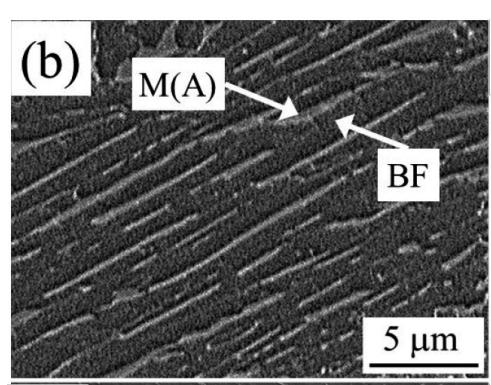
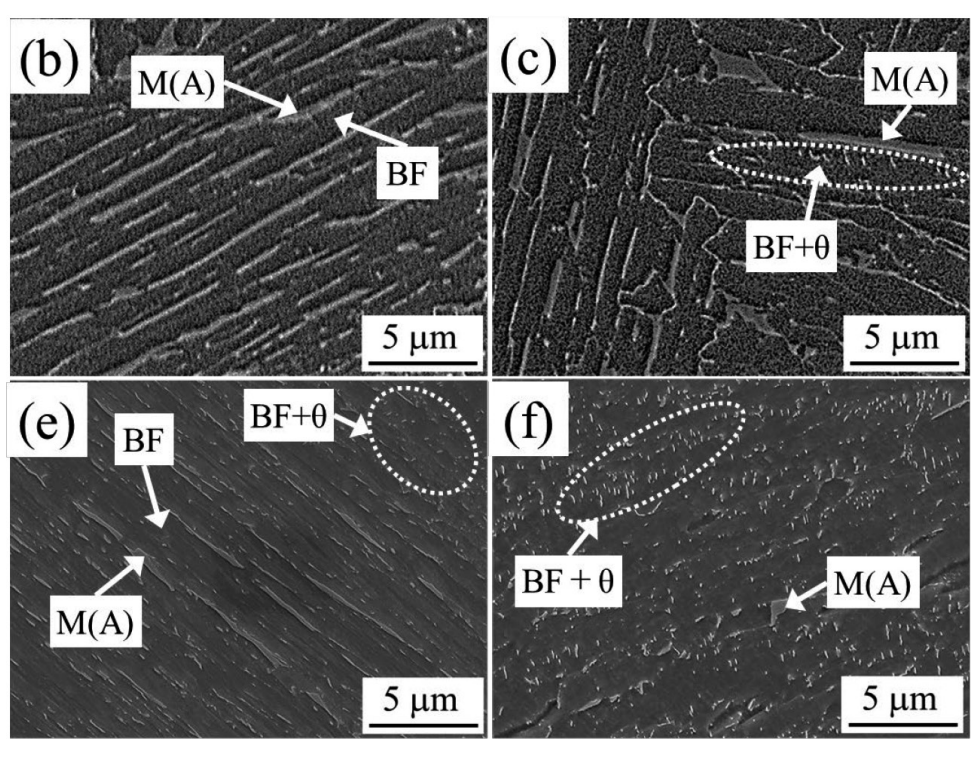

(f)

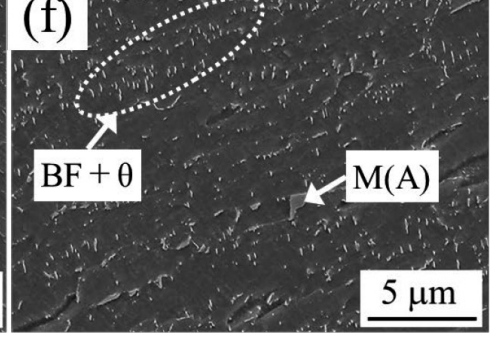

Fig. 7. (a) Dilatation during isothermal holding at $500^{\circ} \mathrm{C}$, SEM images after (b) $30 \mathrm{~s}$ and (c) $200 \mathrm{~s}$ of isothermal holding. (d) Dilatation during isothermal holding at $450^{\circ} \mathrm{C}, \mathrm{SEM}$ images after (e) $30 \mathrm{~s}$ and (f) $100 \mathrm{~s}$ of isothermal holding. 
(a)

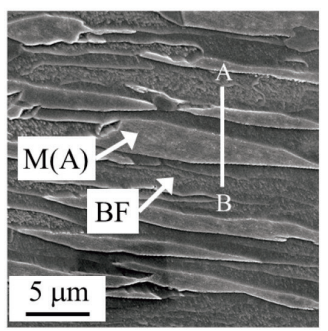

(b)

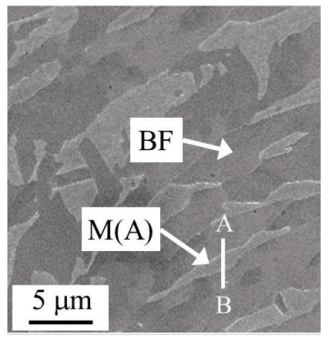

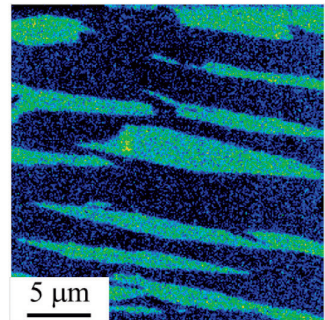
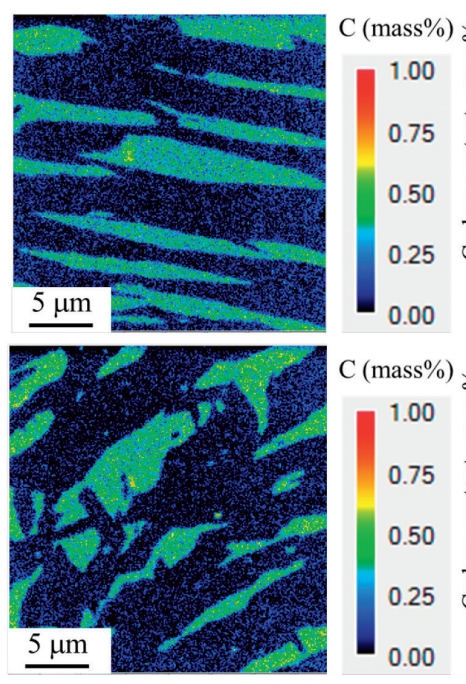
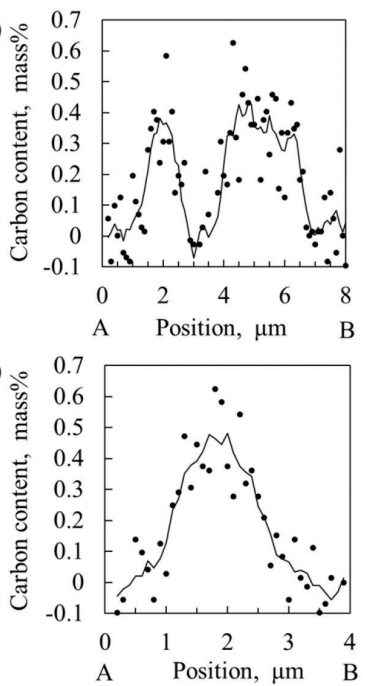

Fig. 8. SEM images, carbon concentration mappings and line profiles of samples held at $600^{\circ} \mathrm{C}$ for (a) $200 \mathrm{~s}$ and (b) $10000 \mathrm{~s}$. The smooth line represents the $\pm 0.2 \mu \mathrm{m}$ moving average.
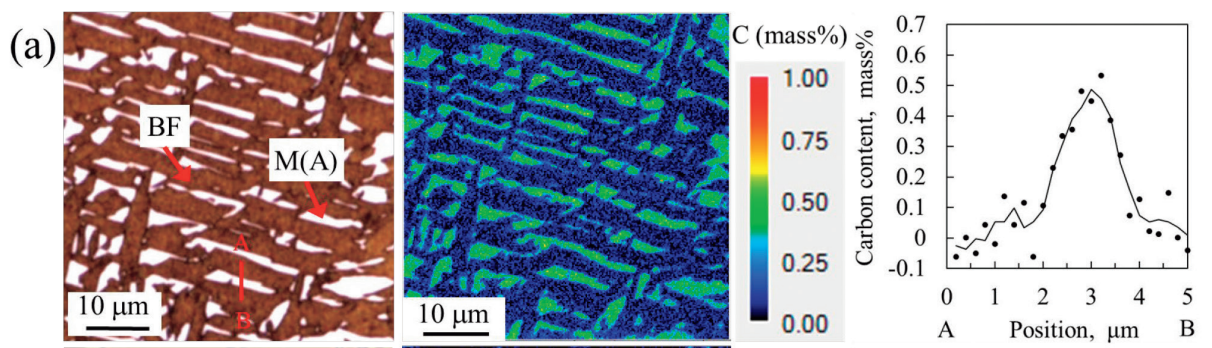

(b)
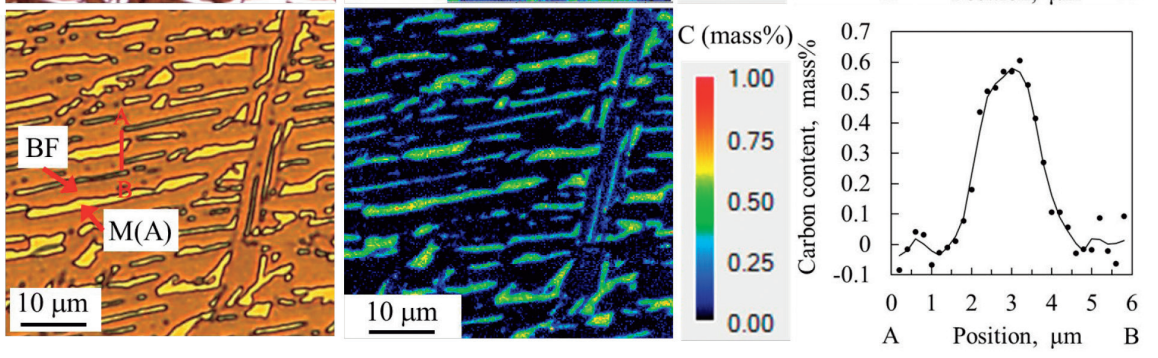

Fig. 9. Optical micrographs, carbon concentration mappings and line profiles of samples held at $550^{\circ} \mathrm{C}$ for (a) $100 \mathrm{~s}$ and (b) $1000 \mathrm{~s}$. The smooth line represents the $\pm 0.2 \mu \mathrm{m}$ moving average.

(a)

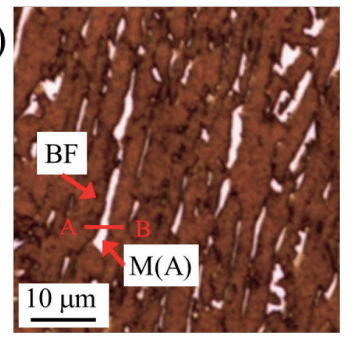

(b)

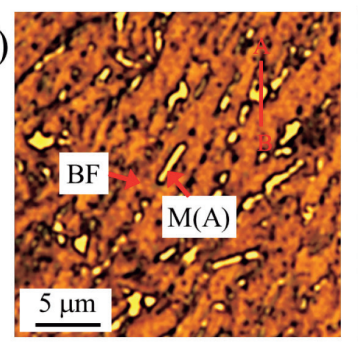

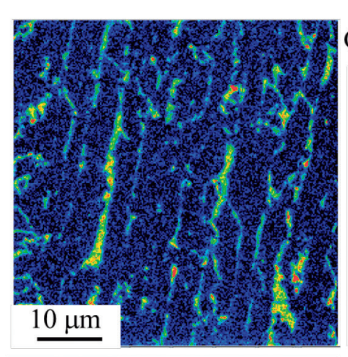
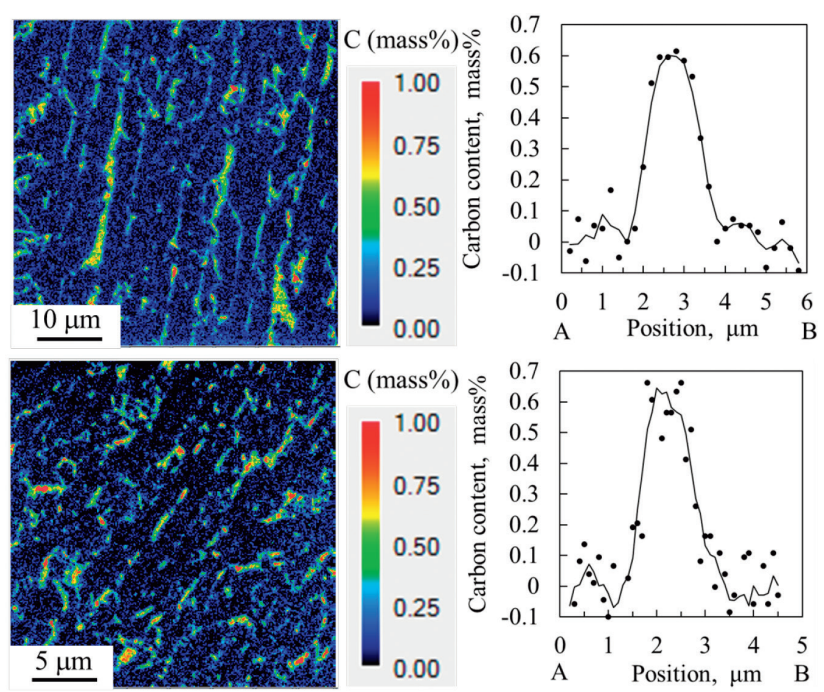

Fig. 10. SEM images, carbon concentration mappings and line profiles of samples held at (a) $500^{\circ} \mathrm{C}$ and (b) $450^{\circ} \mathrm{C}$ for $100 \mathrm{~s}$. The smooth line represents the $\pm 0.2 \mu \mathrm{m}$ moving average. 
約 $100 \mathrm{~J} / \mathrm{mol}$ に相当した。この変態停留は, ベイナイトの不 完全変態に起因すると考えられる。その後, 再度膨張が再 開することで, 未変態 $\gamma$ の 濃度は, $T_{0}$ 組成を超えてNPLE 成長限界に対応するNPLE/PLE境界に近づいた $(300-$ $1000 \mathrm{~s})$ 。その後, さらに長時間保持 (>1000 s) すると, 未 変態 $\gamma$ の 濃度は減少し, 変態停留時 $(50-300 \mathrm{~s})$ の未変態 $\gamma$ の 濃度とほぼ同程度となった。再度膨張が再開し, 未変 態 フェライト変態が生じていることを示唆する。このことか ら, $550^{\circ} \mathrm{C}$ 以上の等温保持においては, フェライト変態が生 じている可能性があり, ベイナイト変態に伴う変態停留を 議論するためには，これらの影響を考慮する必要がある。 次いで, 長時間保持で未変態 $\gamma$ の濃度が減少したのは, 高Cの未変態双ら優先的に炭化物の析出が生じ, それに 伴い, $\mathrm{FCC} \rightarrow \mathrm{BCC}$ 変態が再度進行し, 高 $\mathrm{C}$ の未変態 $\gamma$ が消 失した結果, $\gamma$ 粒ごとのC 濃化のバラッキによって, C濃度 が低い未変態 $\gamma$ 粒が残存したことが要因と考えられる。 $\gamma$ 粒 ごとにC濃度にバラツキが生じる要因として, ベイナイト 変態が生じるタイミングの違いが挙げられる。この場合, 未変態 $\gamma$ の平均 C 濃度に対して, 各未変態 $\gamma$ 粒のC 濃度の個 值のバラッキが大きくなることが予想される。しかしなが ら, 今回の未変態 $\gamma$ の 濃度測定 (各試料 10 個の $\gamma$ 粒評価) では, C濃度が高い未変態 $\gamma$ 粒が評価され, C濃度が低い未 変態 $\gamma$ 粒は評価するに至らず，エラーバーが小さくなった と推察される。 $\gamma$ 粒ごとのC濃度のバラツキと相変態挙動 の関係については, 更なる詳細な研究で明らかにする必要 がある。なお，長時間保持（>1000 s) したときに炭化物が 析出する要因は, $\gamma$ 粒ごとのC濃度のバラッキだけでなく, $\gamma / \alpha$ 界面において, para平衡またはNPLE/PLE境界となるC 濃度までC 分配が生じると炭化物の析出駆動力が大きくな ることも関連すると考えられる。

$500^{\circ} \mathrm{C}$ 保持における未変態 $\gamma$ の 濃度の時間変化を Fig. 11 (b) に示す。 $550^{\circ} \mathrm{C}$ 保持で観測される膨張の再開打よび変 態停留後の未変態 $\gamma$ の濃度の上昇は見られず, $500^{\circ} \mathrm{C}$ 保持
では未変態yのC濃度はほぼ一定であった。この結果は, $500^{\circ} \mathrm{C}$ 以下では拡散変態が生じにくいことが関連している と推察される。

\section{$4 \cdot 2450^{\circ} \mathrm{C}$ おび $500^{\circ} \mathrm{C}$ 保持における未変態 $y$ と炭化物析 出の関係}

$450^{\circ} \mathrm{C}$ および $500^{\circ} \mathrm{C}$ 保持では, $100 \mathrm{~s}$ の短時間保持でも $\mathrm{BF}$ ラス間に炭化物が析出し, 長時間保持するほど未変態 $\gamma$ の 体積分率が減少する傾向を示した。べイナイトラスが成長

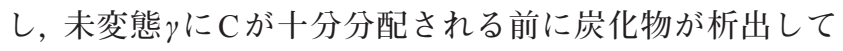
いるならば, そのときの未変態 $\gamma$ の濃度は, 不完全変態 に伴う未変態 $\gamma$ の濃度の上限とは必ずしも一致しない可 能性がある。Azumaらは, BF と炭化物が個別に析出するこ とを仮定し, ベイナイト変態のモデル化を検討する中で, $\gamma$ 中に打ける炭化物の析出は, BFの生成に対して十分に遅 いことを計算で示している ${ }^{28)}$ 。このことと, $500^{\circ} \mathrm{C}$ 以下では フェライト変態はほとんど生じないことを勘案すると, 膨 張停止時の未変態 $\gamma$ の 濃度は, 炭化物析出がたとえ進行 していても, ベイナイトの不完全変態に伴う未変態 $\gamma$ の 濃度に対応すると考えられる。

\section{$4 \cdot 3$ 未变態 $\gamma$ の 濃度と状態図の関係}

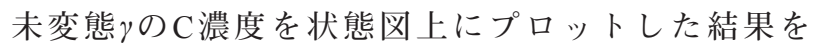
Fig.12に示す。中塗のプロットは, 変態停留時 $(100 \mathrm{~s}$ また は200 s) の未変態 $\gamma$ の濃度, 中空のプロットは, $650^{\circ} \mathrm{C}$ 保 持におけるフェライト変態, および, $600-550^{\circ} \mathrm{C}$ で変態停 留後再度膨張が開始したとき（長時間保持）の未変態 $\gamma$ の $\mathrm{C}$ 濃度, をそれぞれ示している。变態停留時の未变態人のC 濃度は, $\mathrm{T}_{0}$ '組成から $\mathrm{T}_{0}$ 組成の範囲に最もよく対応した。一 方, WBs 限界組成のC濃度とは $0.2 \%$ 以上乘離した。このこ とから, ベイナイト変態に伴う未変態 $\gamma$ の濃度の予測に

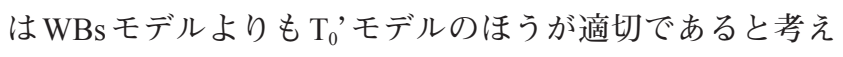
られる。それぞれのモデルの観点での過冷度の評価につい ては次節以降で考察する。

一方, $600-550^{\circ} \mathrm{C}$ 保持で長時間保持した場合, $\mathrm{T}_{0}$ 組成を 超えて, NPLE成長限界に対応するNPLE/PLE境界に近づ
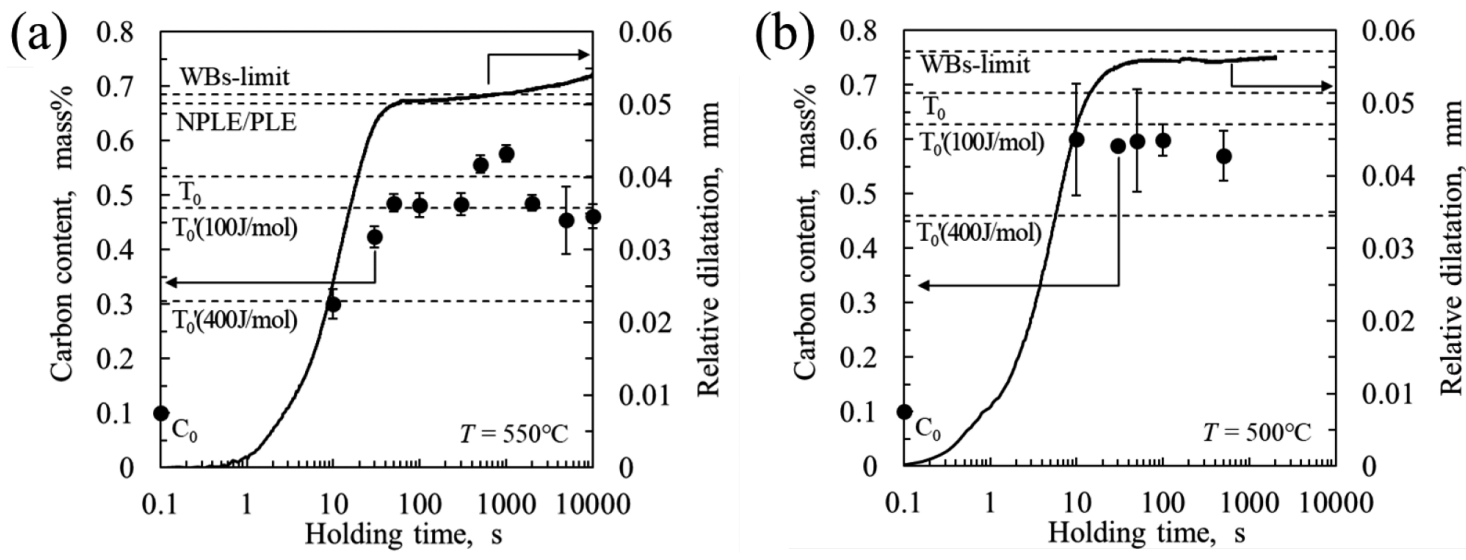

Fig. 11. Change in carbon concentration of austenite during isothermal holding at (a) $550^{\circ} \mathrm{C}$ and (b) $500^{\circ} \mathrm{C}$. The solid line represents the dilatation during the isothermal holding. 
く傾向を示した。また $650^{\circ} \mathrm{C}$ 保持によるフェライト変態に おいて, 未変態 $\gamma$ の濃度はNPLE/PLE境界近傍まで上昇 し, Liu ら, Furuhara $ら^{21,22)}$, Yamashita $~^{19)}$ の従来検討とよ く一致した。

\section{4・4 $\mathrm{T}_{0}$ ' モデルに基づくベイナイトの不完全変態メカニズム}

ベイナイトの不完全変態に伴う変態停留メカニズムを $\mathrm{T}_{0}$ ' モデルの観点で考察する。まず, $450{ }^{\circ} \mathrm{C}$ 保持における 未変態 $\gamma$ の濃度は, $\mathrm{T}_{0}$ 組成からの過冷度 $(\Delta)$ で見ると, $300-400 \mathrm{~J} / \mathrm{mol}$ に相当した。これは, Bhadeshiaが提案して いる BF ラス生成に伴うひずみエネルギー $(400 \mathrm{~J} / \mathrm{mol})$ と 比較的よく一致することから, $\mathrm{T}_{0}$ ' モデルでベイナイトの 不完全変態を説明できると考えられる。一方，保持温度が 高くなるにつれて, $\mathrm{T}_{0}$ からの過冷度が小さくなる傾向を示 し, $550^{\circ} \mathrm{C}$ 保持では $100 \mathrm{~J} / \mathrm{mol}$ 程度, $600^{\circ} \mathrm{C}$ 保持では $0-100 \mathrm{~J} /$ molに対応した。この結果は, Bhadeshiaが提案する $\mathrm{T}_{0}{ }^{\prime}(400$ $\mathrm{J} / \mathrm{mol}$ ) 組成のC濃度に対して $0.2 \%$ 程度高く, 明らかにそれ を超えるものである。Furuharaらは, Fe - 0.15C - 1.5Mn$0.03 \mathrm{Nb}$ 鋼を $600^{\circ} \mathrm{C}$ で保持したときの未変態 $\gamma$ の濃度を, $\alpha$ および $\mathrm{J} / \mathrm{mol}$ ) に相当すると述べている ${ }^{29)}$ 。膨張曲線を用いて等温 保持中の変態停留を確認し, 未変態 $\gamma$ の C 濃度を FE-EPMA で実測した今回結果はこれに近い結果を示唆した。

$\mathrm{T}_{0}$ 組成からの過冷度が $400 \mathrm{~J} / \mathrm{mol}$ よりも小さくなるメカ ニズムとして, 以下の 2 点が考えられる。(1) 保持温度が高 温となり, 変態ひずみの塑性緩和が生じたことで $\mathrm{T}_{0}$ 組成か らの過冷度が小さくなった可能性 ${ }^{30)}$, (2) Bhadeshiaが提案 する BF生成時のひずみエネルギー400 J/mol は孤立したサ ブユニットを対象とした場合であり，複数のBFが生成す る場合には互いにひずみを緩和しあうことで過冷度が小さ くなった可能性 ${ }^{31)}$ ，が挙げられる。しかしながら，(1)には $\mathrm{T}_{0}$ 組成からの過冷度に温度依存性があるのに対して，(2) には温度依存性がないことから，今回結果を踏まえると (1) のメカニズムに従うと考えられる。保持温度が高温と なることで変態ひずみの塑性緩和が生じる要因には, オー

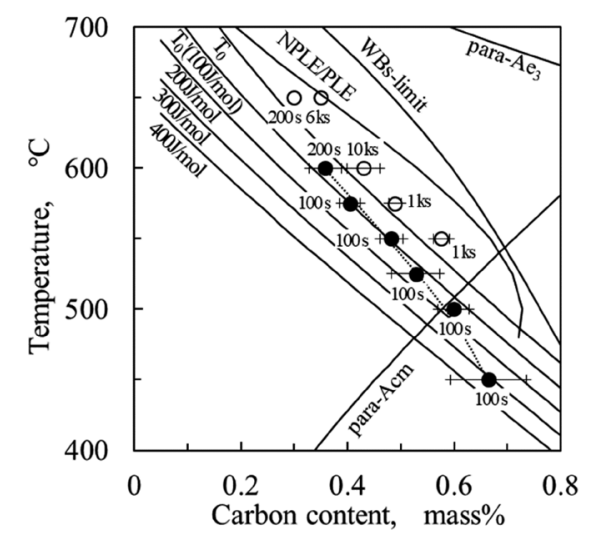

Fig. 12. Phase diagram of the steel used with the experimentally observed carbon concentration of untransformed austenite.
ステナイト強度の温度依存性が関連すると考えられるが, その定量性については課題である。

\section{4・5 WBsモデルとの過冷度の比較}

今回実験で得られた変態停留時の未変態 $\gamma$ の 濃度に対 する $\Delta G$ の温度依存性は, 過去のデータに対して報告され ている例 ${ }^{32)}$ と同様にHillertらが報告しているWBs 過冷度 と類似の温度依存性を示した（Fig.13）。この差はいずれの 温度に打いても $100 \mathrm{~J} / \mathrm{mol}$ 程度と大きくはないが, WBs 過 冷度の見積もりの理論的根拠が明確でないために, この差 を説明することは容易ではない。Hillertら ${ }^{10)}$ はWBs過冷 度を以下の要領で導出している。まず, $\mathrm{C}$ 量をさまざま変 えた鋼 $\left(\mathrm{C}\right.$ 濃度 : $\left.x_{0}\right)$ を対象として, $700^{\circ} \mathrm{C}^{9)}$ および $300^{\circ} \mathrm{C}^{33)}$ で等温保持したときのアシキュラーフェライトの成長速 度 $(v)$ を求める。Zener-Hillertの式 ${ }^{34)}$ によると, アシキュ ラーフェライトの成長速度と $\mathrm{C}$ 濃度の積の $1 / 2$ 乗 $\left(\left(v x_{0}\right)^{1 / 2}\right)$ と $\mathrm{C}$ 濃度 $\mathrm{x}_{0}$ の間に線形の関係があることから, 成長速度が ゼロとなるC濃度を外挿により求め, これをアシキュラー フェライトの成長が停止する組成とする。また, X線回折 から得られる $\gamma$ の格子定数を未変態 $\gamma$ のC濃度に換算する ことで求めた $450^{\circ} \mathrm{C}$ 保持における結果 ${ }^{35)}$ を含めた 3 水準の 温度における組成を対象として, para- $\mathrm{Ae}_{3}$ 組成からの過冷 度 $(\Delta G)$ を求めている。加えて, 自然な温度変化をとるよ うに, 一 $200^{\circ} \mathrm{C}$ および $800^{\circ} \mathrm{C}$ での $\Delta G$ を恣意的に選んでいる。 これら 5 水準の温度での $\Delta G$ をスプライン関数で補間する ことで, WBs 過冷度の温度変化を得ている。このように, WBs 過冷度の実験的根拠が十分であるとは言い難く, ま た, 物理的背景も明確ではない。したがって, 今回, 変態停 留時の未変態 $\gamma$ の C 濃度と WBs 限界組成のC 濃度が大きく 乘離 $(0.2 \%$ 程度 $) し た$ 理由を考察することは困難である。 近年, para平衡からの過冷度に関してエネルギー散逸の要 因となる因子ごとに分離して評価する試み ${ }^{36)}$ もれれてお り, 今後WBs モデルの理論的背景の構築が期待される。

$\mathrm{T}_{0}$ ' モデルも WBs モデルも過冷度の温度依存性を調整す る必要がある点は共通するが, 実測された変態停留時点で

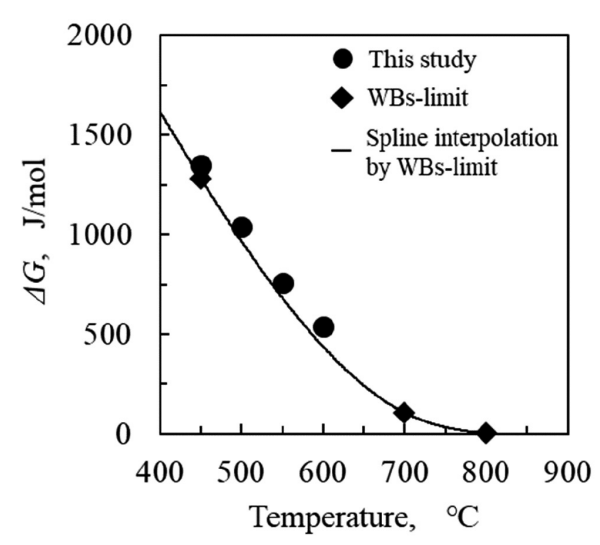

Fig. 13. Comparison of supercooling from para- $\mathrm{Ae}_{3}$ composition $(\Delta G)$ of austenite during transformation stasis and those of WBs limit composition. 
の未変態 $\gamma$ の濃度との乘離の程度が $\mathrm{T}_{0}$ ' モデルのほうが WBs モデルよりも小さい点や, $\mathrm{T}_{0}{ }^{\prime}$ モデルの過冷度は変態 ひずみとその緩和という物理的な現象に関連する因子だけ の影響を考えればよい点から, 今回の結果は, 変態停留時 の未変態 $\gamma$ 中の $\mathrm{C}$ 濃度予測に対する $\mathrm{T}_{0}$ ' モデルの優位性を示 すものと考える。

\section{5. 結言}

フェライト変態打よびベイナイト変態に伴う変態停留 メカニズムを検討するため, $\mathrm{Fe}-0.1 \mathrm{mass} \% \mathrm{C}-0.5 \% \mathrm{Si}-$ $2.0 \% \mathrm{Mn}$ 合金を $450-650^{\circ} \mathrm{C}$ で等温保持し, 線膨張の時間変 化をもとに, 変態停留したときと変態再開時の未変態 $\gamma$ へ のCの分配挙動をFE-EPMAを用いて解析し, 以下の結論 を得た。

(1) $\mathrm{Fe}-0.1 \% \mathrm{C}-0.5 \% \mathrm{Si}-2.0 \% \mathrm{Mn}$ 合金を $550^{\circ} \mathrm{C}$ で等温保持 すると, $50-300 \mathrm{~s}$ で膨張が停止し, 明膫な変態停留が 生じたのち, 長時間保持で再度膨張が再開し, 变態が 再開する挙動を示した。変態停留するときの未変態 のC 濃度は $\mathrm{T}_{0}{ }^{\prime}(100 \mathrm{~J} / \mathrm{mol})$ に相当した。変態停留が終 了し, 再度変態が再開すると, 未変態 $\gamma$ の 濃度は $\mathrm{T}_{0}$ 組成を超えて, NPLE/PLE境界に近づいた。このこと は, ベイナイトの不完全変態に伴う変態停留に次いで, フェライト変態が生じていることを示唆する。

(2) $450-600^{\circ} \mathrm{C}$ 保持におけるべイナイト変態に伴う未変態 $\gamma$ の $\mathrm{C}$ 濃度は $\mathrm{T}_{0}$, 組成に相当した。 $T_{0}$ 組成からの過冷度 は, 高温ほど小さくなる傾向を示した。保持温度が高 温となることで変態ひずみの塑性緩和が生じたことで $\mathrm{T}_{0}$ 組成からの過冷度が小さくなったと考えられる。

（3）未変態 $\gamma の C$ 濃度の温度依存性は, WBs 限界組成の温 度依存性と類似の傾向を示した。しかしながら, 未変 態 $\gamma$ の C 濃度はWBs 限界組成のC濃度に対して大きく 乘離 $(0.2 \%$ 程度 $)$ していた。変態停留による未変態 $\gamma$ の $\mathrm{C}$ 濃度は, 変態ひずみの温度依存性を考慮した $\mathrm{T}_{0}{ }^{\prime}$ モデ ルで精度よく予測することができる。

\section{文献}

1 ) H.Mimura, M.Iino, H.Haga, N.Nomura, K.Aoki and K.Aoki: Trans. Jpn. Weld. Soc., 1(1970), 28.

2 ) Y.Kasamatsu, S.Takashima and T.Hosoya: Tetsu-to-Hagané, 65(1979), 1222 (in Japanese). https://doi.org/10.2355/tetsutohagane1955.65.8_ 1222

3 ) V.F.Zackay, E.R.Parker, D.Fahr and R.Busch: Trans. Am. Soc. Met., 60(1967), 252

4 ) T.Maki, H.Onodera and I.Tamura: J. Soc. Mater. Sci. Jpn., 24(1975), 150 (in Japanese). https://doi.org/10.2472/jsms.24.150

5 ) H.K.D.H.Bhadeshia and D.V.Edmonds: Acta Metall., 28(1980), 1265. https://doi.org/10.1016/0001-6160(80)90082-6

6 ) H.K.D.H.Bhadeshia: Acta Metall., 29(1980), 1117. https://doi.org/10. 1016/0001-6160(81)90063-8

7 ) F.G.Caballero, C.Garcia-Mateo, M.J.Santofimia, M.K.Miller and
C.García de Andrés: Acta Mater., 57(2009), 8. https://doi.org/10. 1016/j.actamat.2008.08.041

8 ) F.G.Caballero, M.K.Miller, C.Garcia-Mateo and J.Cornide: $J$. Alloy. Compd., 577(2013), S626. https://doi.org/10.1016/j.jallcom. 2012.02.130

9 ) M.Hillert: The Growth of Ferrite, Bainite and Martensite, Internal Report, Swedish Institute for Metals Research, Stockholm, (1960).

10) M.Hillert, L.Höglund and J.Ågren: Metall. Mater. Trans. A, 35(2004), 3693. https://doi.org/10.1007/s11661-004-0275-5

11) H.I.Aaronson, W.T.Reynolds Jr. and G.R.Purdy: Metall. Mater Trans. A, 35(2004), 1187. https://doi.org/10.1007/s11661-004-0294-2

12) H.Chen, K.Zhu, L.Zhao and S.van der Zwaag: Acta Mater., 61(2013), 5458. https://doi.org/10.1016/j.actamat.2013.05.034

13) C.Zener: Trans. Met. Soc. AIME, 167(1946), 550.

14) H.-D.Wu, G.Miyamoto, Z.-G.Yang, C.Zhang, H.Chen and T.Furuhara: Acta Mater., 133(2017), 1. https://doi.org/10.1016/j.actamat.2017.05. 017

15) G.Miyamoto and T.Furuhara: CAMP-ISIJ, 31(2018), 286, CD-ROM (in Japanese).

16) G.I.Rees and H.K.D.H.Bhadeshia: Mater. Sci. Technol., 8(1992), 985. https://doi.org/10.1179/mst.1992.8.11.985

17) C.Zener: J. Appl. Phys., 20(1949), 950. https://doi.org/10.1063/1. 1698258

18) K.Oi, C.Lux and G.R.Purdy: Acta Mater., 48(2000), 2147. https:// doi.org/10.1016/S1359-6454(00)00041-0

19) T.Yamashita, M.Enomoto, Y.Tanaka, H.Matsuda and M.Nagoshi: ISIJ Int., 58(2018), 1079. http://doi.org/10.2355/isijinternational. ISIJINT-2018-026

20) T.Yamashita, M.Enomoto, Y.Tanaka, H.Matsuda and K.Okuda: ISIJ Int., 60(2020), 369. https://doi.org/10.2355/isijinternational. ISIJINT-2019-395

21) Z.-Q.Liu, G.Miyamoto, Z.-G.Yang and T.Furuhara: Acta Mater., 61(2013), 3120. https://doi.org/10.1016/j.actamat.2013.02.003

22) T.Furuhara, T.Chiba, T.Kaneshita, H.Wu and G.Miyamoto: Metall. Mater. Trans. A, 48(2017), 2739. https://doi.org/10.1007/s11661-0174064-3

23) R.A.Grange and H.M.Stewart: Trans. AIME, 167(1946), 467.

24) R.Castaing: Adv. Electron. Electron Phys., 13(1960), 317. https:// doi.org/10.1016/S0065-2539(08)60212-7

25) E.C.Bain and H.W.Paxton: Alloying Elements in Steel, 2nd ed., ASM, Metals Park, Ohio, (1961), 4.

26) H.Kawata, K.Fujiwara and M.Takahashi: ISIJ Int., 57(2017), 1866. https://doi.org/10.2355/isijinternational.ISIJINT-2017-239

27) K.Tsuzaki, K.Fujiwara and T.Maki: Mater. Trans. JIM, 32(1991), 667. https://doi.org/10.2320/matertrans1989.32.667

28) M.Azuma, N.Fujita, M.Takahashi, T.Senuma, D.Quidort and T.Lung: ISIJ Int., 45(2005), 221. https://doi.org/10.2355/isijinternational.45.221

29) T.Furuhara, T.Yamaguchi, G.Miyamoto and T.Maki: Mater. Sci. Technol., 26(2010), 392. https://doi.org/10.1179/026708309X12512744

30) M.Takahashi, Y.Watanabe and H.Tamehiro: Proc. Int. Conf. on Solid-Solid Phase Transformation '99 (JIMIC-3), ed. by M. Koiwa, K. Otsuka and T. Miyazaki, JIM, Sendai, (1999), 1176.

31) H.K.D.H.Bhadeshia: Bainite in Steels, Theory and Practice, 3rd. ed., Maney Publishing, U.K., (2015), 117.

32) L.Leach, P.Kolmskog, L.Höglund, M.Hillert and A.Borgenstam: Metall. Mater. Trans. A, 49(2018), 4509. https://doi.org/10.1007/ s11661-018-4819-5

33) G.R.Speich and M.Cohen: Trans. AIME, 218(1960), 1050.

34) M.Hillert: Jernkontorets Ann., 141(1957), 757.

35) K.Tsuzaki, A.Kodai and T.Maki: Metall. Mater. Trans. A, 25(1994), 2009. https://doi.org/10.1007/BF02649049

36) G.Miyamoto and T.Furuhara: ISIJ Int., 60(2020), 2942. https://doi. org/10.2355/isijinternational.ISIJINT-2020-216 